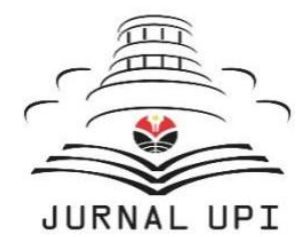

JOURNAL OF APPLIED FOOD AND NUTRITION

Volume 1 Nomor 1, June 2020, 30-37

Available online at:

https://ejournal.upi.edu/index.php/JAFN

\title{
Nutritional Status Assessment of West Java Athletes: A Preliminary Studies
}

\author{
Syifa F. Syihab*, Widya Astuti, Muchamad Rizki Sentani, Isti Kumalasari \\ Universitas Pendidikan Indonesia, Jl. Dr. Setiabudhi No. 229, Bandung 40154, Indonesia \\ * Corresponding Author. E-mail: syifasyihab@upi.edu (Syifa F. Syihab)
}

\section{A B S T RA C T S}

The nutritional adequacy of athletes is one of the important factors that support sports performance. The fulfillment of proper nutrition based on the individual athlete's needs is the main prerequisite for health, physical fitness, and sports performance, especially during an undergoing competition. This study aims to see the nutritional adequacy and anthropometric conditions of athletes from various sports. The subjects are West Java athletes who are undergoing the initial training program held by Indonesia National Sports Committee. This research is a preliminary assessment, and it was expected as a reference in the general preparation stage of a training center program for the next 6 months. The anthropometric data were collected using the Omron HBF 375 Karada Scan Body Composition Monitor and Stadiometer, while the data collection on the adequacy of energy and nutrients used the 24-hour Food Recall. The results showed that most athletes had a nutritional status of obesity due to restrictions on exercise activities during the Covid19 pandemic. $17.4 \%$ of athletes had an obesity category, had $18.78 \%$ of athletes had normal muscle mass. Meanwhile, women's volleyball is classified as low. The level of energy sufficiency in women's handball, women's softball, and men's bodybuilding have exceeded the level of daily energy requirement. An athlete nutrition assistance is needed based on the type of sport and individual needs.
A R T I C L E I N F O

Article History:

Received April 2020

Revised April 2020

Accepted May 2020

Available online June 2020

Keywords:

Athletes; Body Mass

Index; Body Fat; Energy

Expenditure; Nutrition

Requirement; Nutritional

Status 


\section{Introduction}

One of the important factors in the prime physical condition and optimal performance of an athlete is the fulfillment of proper nutrition. Adequate food intake is needed for normal growth and development processes, maintaining health and well-being, reducing the risk of disease and injury, and optimizing sports performance ${ }^{(1)}$. In addition to genetic factors and an efficient training program, a good diet plan certainly greatly determines their performance also determines their performance in sports ${ }^{(2)}$.

Food intake was directly correlated with energy adequacy. If the energy obtained from daily food consumption is insufficient or exceeds energy expenditure, this situation can lead to a negative impact on body mass, body composition, and function, and interfering with their performance. When energy consumption is greater than energy expenditure, the body will convert the excess energy into fat tissue and can interfere with athlete motor skills and performance ${ }^{(3)}$. On the other hand, a lack of food intake can lead to a lack of energy supply, and if this condition persists for a long period there can be a deficiency of macronutrients and micronutrients. Athlete's nutritional status is a basic parameter that can be used to measure the nutritional adequacy of athletes. Lack of energy can inhibit the growth of the athlete's body, cause physiological disturbances, weight loss, and can further reduce performance, and increase the risk of injury ${ }^{(4)(5)}$. Athletes who get nutritional intake according to individual characteristics and sports will have adequate nutrition to train and improve performance in sports ${ }^{(6)}$.

The physiological demands of team sports are various and can include a range of performance types ${ }^{(7)(8)}$. The various nature of team sport exercise requires the use of both anaerobic and aerobic systems to fuel performance. Therefore, each team sport and position within the sport, depending on the nature of training and competition, will have unique energy demands and nutrient requirements ${ }^{(8)}$. Fulfilling nutritional intake is substantial for an athlete, but often athletes do not get the right nutritional intake. This situation mostly happens due to a lack of nutrition knowledge among athletes, as well as a lack of nutrition education among coaches, officials, administrators, as well as a lack of nutrition and health personnel who understand and have competence in the science of achievement sports nutrition ${ }^{(6)}$. Currently, there are not many studies examining the nutritional needs and adequacy of sports athletes in West Java.

As mentioned earlier, a nutritional status which includes nutritional needs and nutritional adequacy of athletes is an important factor affecting an athlete's performance in competition. This study aims to obtain basic information related to the nutritional status of athletes and the level of nutritional adequacy of athletes, so that it can become the basis for formulating athletes nutritional assistance programs.

\section{Materials and Methods}

This research was conducted at the Training Center for the Indonesian National Sports Committee (KONI), West Java. The research was designed with a correlational survey method with a cross-sectional approach. The population in this study were West Java athletes who will be participated in the 2021 National Sports Event. Sampling in this research was using the purposive sampling technique. Respondents were divided into 4 categories, based on the sports characteristics, namely power, strength, endurance, and games. The inclusion criteria are athletes who don't have an infectious disease, are not involved in a weight management 
program, and were willing to participate in this research. Meanwhile, the exclusion criteria were athletes who did not attend the data collection and athletes who don't complete the questionnaire. The instruments used in this study were Omron HBF 375 Karada for measuring body composition and Seca Stadiometer for anthropometric data collection. The questionnaire instrument consists of 1) Characteristics of respondents, 2) Nutritional status of athletes, 3) Needs of energy and nutrients, 4) 24 hours of a food recall. Data analysis was carried out by descriptive quantitative method.

\section{Results and Discussion}

\subsection{Athletes Characteristic}

The total number of respondents involved in this study was 23 subjects, consisting of 9 male athletes and 14 female athletes. Educational background, occupation, types of sport, age of debut, frequency, and duration of training were shown in Table 1. These athletes come from 9 sports categories, consisting of handball, volleyball, $3 \times 3$ basketball, fencing, athletics, softball, wrestling, bodybuilding, and boxing. The average age of the subjects was ranged from 26 years for male athletes and 23 years for female athletes. Both male and female athletes, commonly have graduated from the bachelor's program.

Most of the female athletes were a student $(66.6 \%)$, while male athletes $(56 \%)$ is focusing on their carrier as an athlete. The age of debut was range from 15-16 years; this shows that the two groups of subjects started their sports careers in the teenage age category. Since these athletes were in the Training Centre, the training frequency and duration were the same. Both female and male athletes have a training session of 3 hours per day and 6 times per week.

Table 1. Athletes Characteristic

\begin{tabular}{lcc}
\hline \multirow{2}{*}{ Subject characteristic } & \multicolumn{2}{c}{ Group } \\
\cline { 2 - 3 } & Male Athletes & Female Athletes \\
\hline Age (Mean \pm SD) & $26 \pm 9.4$ & $23 \pm 3.4$ \\
Education n (\%) & $3(33.4)$ & $5(35.7)$ \\
$\quad$ Highschool & $6(66.6)$ & $8(57.2)$ \\
Bachelor & $0(0.0)$ & $1(7.1)$ \\
Magister & & \\
Occupation n (\%) & $2(22)$ & $8(57.2)$ \\
Students & $1(11)$ & $1(7.1)$ \\
Private employee & $1(11)$ & $0(0.0)$ \\
Entrepreneur & $5(56)$ & $5(35.7)$ \\
Unemployment & & \\
Sport n (\%) & $2(22)$ & $2(14.3)$ \\
Handball & $2(22)$ & $2(14.3)$ \\
Volleyball & $2(22)$ & $2(14.3)$ \\
Basketball & $1(11)$ & $1(7.1)$ \\
Fencing & $0(0.0)$ & $2(14.3)$ \\
Athletic & $0(0.0)$ & $3(21.5)$ \\
Softball & $1(11)$ & $1(7.1)$ \\
Wrestling & $1(11)$ & $0(0.0)$ \\
Bodybuilding & &
\end{tabular}




\begin{tabular}{lcc}
\hline \multirow{2}{*}{ Subject characteristic } & \multicolumn{2}{c}{ Group } \\
\cline { 2 - 3 } & Male Athletes & Female Athletes \\
\hline Boxing & $0(0.0)$ & $1(7.1)$ \\
Age of debut (Mean \pm SD) & $16 \pm 2.4$ & $15 \pm 3.8$ \\
Frequency (Times/ week) & $8 \pm 2.4$ & $6 \pm 2.7$ \\
Duration (hours/ day) & $3 \pm 0.4$ & $3.3 \pm 1.6$ \\
\hline
\end{tabular}

\subsection{Athletes Nutritional Status}

Athlete's nutritional status is the main parameter that can be used to measure the nutritional adequacy of athletes. Body composition is the composition of the body which is described by body fat and muscle mass. Determination of the nutritional status of athletes was carried out using a stadiometer (body height) and a Karada Scan Body Composition Meter to measure body mass index and total fat mass. There were 23 athletes from various types of sports, which involved in this study. The athlete's muscle mass and body fat percentage were presented in Table 2. Athlete's muscle mass is categorized into 3 groups, namely, low, normal, and high muscle mass ${ }^{(9)}$. This study shows that $78.3 \%$ of the athletes have normal muscle mass, while $8.7 \%$ have a high muscle mass, and $13.5 \%$ were categorized to have low muscle mass. The large number of athletes who are in the normal category indicates that athletes need a muscle mass increase program to support their performance in competition. Things that need to be considered in the results of this study are the findings of combat sports athletes and bodybuilding that have low muscle mass, and so did in bodybuilding. Combat sport athletes are categorized using body mass as a criterion, and muscle mass is required to support muscle strength ${ }^{(10)}$. Muscle mass is correlated directly with the number of glycogen reserves in muscles. Glycogen in muscles is the main energy reserve used during anaerobic cellular respiration ${ }^{(11)}$.

The percentage of body fat mass was categorized into 4 groups, namely acceptable, athletes, fitness, and obesity. The measurement data shows that $60.9 \%$ of athletes were categorized as acceptable, while $13.0 \%$ categorized as fitness, and only $8.7 \%$ of athletes were categorized as athletic. The result also showed that there were $17.4 \%$ athletes that categorized as obese. Most athletes admit that activities restriction during the Covid-19 pandemic, has limited their training and exercise program. Study in US shows that during Covid-19 conefinement, there was a significant decrease in self-reported participation time for strength training, endurance, and mobility, with the largest reduction coming from participation time in sport-specific activities among athletes ${ }^{(12)}$. A disruptions in proper physical training for athletes can increased risk of future injuries when athletes return to play ${ }^{(13)}$.

Table 2. Athletes muscle mass and fat percentage

\begin{tabular}{lc|c|c|c|c|c|c}
\hline \multirow{1}{*}{ Sport } & \multicolumn{3}{c}{$\begin{array}{c}\text { Muscle mass } \\
\mathrm{n}=23\end{array}$} & \multicolumn{5}{c}{$\begin{array}{c}\text { Fat percentage } \\
\mathrm{n}=23\end{array}$} \\
\cline { 2 - 9 } & Low & Normal & High & Acceptable & Athlete & Fitness & Obesity \\
\hline Hand ball $(\mathrm{n}=4)$ & 0 & 3 & 1 & 3 & 1 & 0 & 0 \\
Indoor & 0 & 4 & 0 & 3 & 0 & 1 & 0 \\
volleyball $(\mathrm{n}=4)$ & 0 & 4 & 0 & 3 & 0 & 0 & 1 \\
3 on 3 & 0 & & & & &
\end{tabular}




\begin{tabular}{|c|c|c|c|c|c|c|c|}
\hline \multirow[t]{2}{*}{ Sport } & \multicolumn{3}{|c|}{$\begin{array}{l}\text { Muscle mass } \\
n=23\end{array}$} & \multicolumn{4}{|c|}{$\begin{array}{l}\text { Fat percentage } \\
n=23\end{array}$} \\
\hline & Low & Normal & High & Acceptable & Athlete & Fitness & Obesity \\
\hline \multicolumn{8}{|l|}{ basketball $(n=4)$} \\
\hline Fencing $(n=2)$ & 0 & 1 & 1 & 0 & 1 & 1 & 0 \\
\hline Athletic $(n=2)$ & 0 & 2 & 0 & 0 & 0 & 1 & 1 \\
\hline Softball $(n=3)$ & 0 & 3 & 0 & 2 & 0 & 0 & 1 \\
\hline Wrestling $(\mathrm{n}=2)$ & 1 & 1 & 0 & 1 & 0 & 0 & 1 \\
\hline $\begin{array}{l}\text { Body building } \\
(\mathrm{n}=1)\end{array}$ & 1 & 0 & 0 & 1 & 0 & 0 & 0 \\
\hline Boxing $(\mathrm{n}=1)$ & 1 & 0 & 0 & 1 & 0 & 0 & 0 \\
\hline Total n (\%) & $3(13.0)$ & $18(78.3)$ & $2(8.7)$ & $14(60.9)$ & $2(8.7)$ & $3(13.0)$ & $4(17.4)$ \\
\hline
\end{tabular}

\section{Energy Expenditure and Nutrition Intake}

Total energy expenditure (TEE) is consist of the energy costs of the processes essential for life (basal metabolic rate (BMR), 60-80\% of TEE), of the energy expended in order to digest, absorb, and convert food (diet-induced thermogenesis, $\sim 10 \%$ ), and the energy expended during physical activities (activity energy expenditure, $\sim 15-30 \%{ }^{(14)}$. Athlete's nutrient intake is the total amount of nutrients consumed during the day, match preparation and post-match recovery. Imbalance energy intake that comes from daily food consumption, can affect body mass, body composition and function of athletes, and reduce performance ${ }^{(3)}$. The energy and nutritional adequacy level of athletes in this study was carried out using the 24-hour Food Recall instrument, to determine the type, amount, and frequency of eating athletes. This activity requires data collection techniques through in-depth interviews to explore the athlete's eating habit.

Energy expenditure data processing in Table 3 shows the athletes' daily TEE is 3189.52 \pm 848.78 calories. During the training camp, the average athlete performs physical exercise in the morning and evening with a duration of 2-3 hours, but has different intensities. The average energy intake in all sports is $3303 \pm 738 \mathrm{kcal}$, which shows that the amount of energy intake is higher than the athlete's energy needs. Similar result was shown in handball, wrestling, bodybuilding, softball, indoor volleyball, and basketball atheletes. Those athletes get a higher energy intake than they should. The excess energy intake of some athletes from these particular sports is caused by the high-carbohydrate diet consumed by athletes. Some atheletes were also encourage by their coaches to gain weight in order to support their performance. This missconcept understanding can lead to the high number of obesity cases in some athletes. Although consuming good carbohydrate sources as fuel that can increase performance before and during exercise, excess carbohydrate intake can cause increased fat storage ${ }^{(15)}$. This increase in fat stores can affect the nutritional status of these athletes. Carbohydrates have an important role in the metabolic system of sports, especially in delaying fatigue, because carbohydrates contribute to energy reserves in the form of glycogen during recovery ${ }^{(16)}$.

Another contributing of the high energy intake in athletes is the habit of snacking fried foods, junk food,and sweet drinks. The number of athletes who have the habit of snacking on high-calorie foods shows the low awareness of athletes in eating healthy foods. Low awareness of athletes can be interpreted as low knowledge of athletes regarding food sources of nutrition. As it is known, nutritional intake is one of the factors that can affect athlete's performance ${ }^{(17)}$. Another study shows that nutrition knowledge was positively correlated with fat free soft tissue 
mass ${ }^{(8)}$. Excessive fat intake can leads to an excess of saturated fatty acids and cholesterol, which can affect their long term health and fitness ${ }^{(18)}$.

Table 3. Athletes Energy Adequacy

\begin{tabular}{|c|c|c|c|c|}
\hline Sports & $\mathrm{n}$ & TDEE $(\mathrm{kkal})^{1}$ & $\begin{array}{l}\text { Energy intake } \\
\text { (kkal) }\end{array}$ & $\begin{array}{c}\text { Energy adequacy } \\
(\%)\end{array}$ \\
\hline \multicolumn{5}{|l|}{ Handball } \\
\hline Male & 2 & $3885.4 \pm 162.6$ & $4443.5 \pm 154.9$ & 114 \\
\hline Female & 2 & $2391.4 \pm 210$ & $4128.5 \pm 1183$ & 172.6 \\
\hline \multicolumn{5}{|c|}{ Indoor volleyball } \\
\hline Male & 2 & $2698.4 \pm 996.1$ & $3046.5 \pm 277.9$ & 113 \\
\hline Female & 2 & $4041.7 \pm 480.7$ & $1231 \pm 910.8$ & 30 \\
\hline \multicolumn{5}{|c|}{ Basketball 3x3 } \\
\hline Male & 2 & $4188.1 \pm 1164.8$ & $2720.0 \pm 359.2$ & 64.9 \\
\hline Female & 2 & $2763.2 \pm 422.6$ & $3095.5 \pm 65.8$ & 73.9 \\
\hline \multicolumn{5}{|l|}{ Softball } \\
\hline Male & - & - & - & - \\
\hline Female & 1 & 2200.6 & 3165 & 143.8 \\
\hline \multicolumn{5}{|l|}{ Wrestling } \\
\hline Male & - & - & - & - \\
\hline Female & 1 & 2508.2 & 2792 & 111.3 \\
\hline \multicolumn{5}{|c|}{ Body building } \\
\hline Male & 1 & 3198 & 6005 & 187.7 \\
\hline Female & - & - & - & - \\
\hline Mean \pm SD & & $3189.52 \pm 848.78$ & $3303 \pm 738$ & 67.4 \\
\hline
\end{tabular}

1: Total Daily Energy Expenditure (TDEE)

The nutritional status of athletes in this study was known to be poor. The number of athletes classified as obese is quite high, and most athletes have an unbalanced amount of energy intake with their daily energy expenditure. A program for assessing nutritional needs and nutritional assistance for athletes is urgently needed in order to assist them in training programs during the competition preparation period. Therefore, athletes' diet programs should be developed based on monitoring their energy expenditure levels to ensure that the recommended energy intake matches their actual energy needs.

\section{Conclusions}

The results showed that most athletes had a nutritional status of obesity due to restrictions on exercise activities during the Covid-19 pandemic. The level of nutritional adequacy of athletes is also known to exceed the amount of daily energy needs. An athlete nutrition assistance is needed based on the type of sport and individual needs.

\section{Acknowledgment}

The authors are grateful for the support from Institute for Research and Community Services of Universitas Pendidikan Indonesia and West Java Indonesia National Sports 
Committee.

\section{References}

${ }^{1}$ Thomas DT, Erdman KA, Burke LM. Position of the Academy of Nutrition and Dietetics, Dietitians of Canada, and the American College of Sports Medicine: Nutrition and Athletic Performance. J Acad Nutr Diet. 2016;116(3):501-28.

${ }^{2}$ Valliant MW, Emplaincourt HP, Wenzel RK. Nutrition Education by a Registered Dietitian Improves Dietary Intake and Nutrition Knowledge of a NCAA Female Volleyball Team. 2012;506-16.

${ }^{3}$ Fräczek B, Grzelak A, Klimek AT. Analysis of Daily Energy Expenditure of Elite Athletes in Relation to Their Sport, the Measurement Method and Energy Requirement Norms. J Hum Kinet. 2019;70(1):81-92.

${ }^{4}$ Burke LM. Energy needs of athletes. Can J Appl Physiol. 2001;26(6 SUPPL.).

${ }^{5}$ Loucks AB. Energy balance and body composition in sports and exercise. J Sports Sci. 2004;22(1):1-14.

${ }^{6}$ Kemenkes RI. Pedoman Gizi Olahraga Prestasi. Izwardy D, editor. Kementerian Kesehatan RI. Jakarta: Kementerian Kesehatan Republik Indonesia; 2014. 1-2 p.

${ }^{7}$ Holway FE, Spriet LL. Sport-specific nutrition: Practical strategies for team sports. J Sports Sci. 2011;29(SUPPL. 1).

${ }^{8}$ Jenner SL, Buckley GL, Belski R, Devlin BL, Forsyth AK. Dietary Intakes of Professional and Semi-Professional Team Sport Athletes Do Not Meet Sport Nutrition Recommendations — A Systematic Literature Review. Nutrients. 2019;11(1160):1-16.

${ }^{9}$ Frisancho AR, Tracer DP. Standards of arm muscle by stature for the assessment of nutritional status of children. Am J Phys Anthropol. 1987;73(4):459-65.

${ }^{10}$ Brito CJ, Roas AFCM, Brito ISS, Marins JCB, Córdova C, Franchini E. Methods of bodymass reduction by combat sport athletes. Int J Sport Nutr Exerc Metab. 2012;22(2):8997.

${ }^{11}$ Maclaren D, Morton J. Biochemistry for Sport and Exercise Metabolism. 1st ed. West Sussex: Blackwell Publishing; 2012.

${ }^{12}$ Jagim AR, Luedke J, Fitzpatrick A, Winkelman G, Erickson JL, Askow AT, et al. The Impact of COVID-19-Related Shutdown Measures on the Training Habits and Perceptions of Athletes in the United States: A Brief Research Report. Front Sport Act Living. 2020;2(December):1-6.

${ }^{13}$ Sarto F, Impellizzeri FM, Spörri J, Porcelli S, Olmo J, Requena B, et al. Impact of Potential Physiological Changes due to COVID-19 Home Confinement on Athlete Health Protection in Elite Sports: a Call for Awareness in Sports Programming. Sport Med [Internet]. 2020;50(8):1417-9. Available from: https://doi.org/10.1007/s40279-02001297-6

${ }^{14}$ Indonesia KKR. Panduan Pendampingan Gizi Atlet. 1st ed. Masyarakat DJK, editor. Jakarta: Kementerian Kesehatan Republik Indonesia; 2021. 9-14 p.

${ }^{15}$ Capling L, Beck KL, Gifford JA, Slater G, Flood VM, O'Connor H. Validity of dietary assessment in athletes: A systematic review. Nutrients. 2017;9(12).

${ }^{16}$ Brown MA, Howatson G, Quin E, Redding E, Stevenson EJ. Energy intake and energy expenditure of preprofessional female contemporary dancers. PLoS One. 2017;12(2):113.

${ }^{17}$ Ismail MN, Wan Nudri WD, Zawiah H. Energy expenditure studies to predict requirements 
of selected national athletes. Malays J Nutr. 1997;3(1):71-81.

${ }^{18}$ Baranauskas M, Stukas R, Tubelis L, Žagminas K, Šurkiene G, Švedas E, et al. Nutritional habits among high-performance endurance athletes. Med. 2015;51(6):351-62. 